Harran Üniversitesi ilahiyat Fakültesi Dergisi

ISSN 1303-2054 | e-ISSN 2564-7741

Yıl: 26, Sayı: 44, Temmuz-Aralık 2020

\title{
SON DÖNEM HÂLIDÎ-NAKŞî ŞEYHLERINDEN ÇELEBI SÜLEYMAN KAYA EFENDI'NIN TASAVUFî DÜŞÜNCESi
}

\author{
SUFI THOUGHTS OF ÇELEBî SÜLEYMAN KAYA (ONE OF THE LATE \\ NAQSHBANDIYYA SHEIKHS) \\ Dr. Öğr. Üyesi Mesut YiĞiT \\ m.yigit@alparslan.edu.tr \\ Orcid ID: https://orcid.org/0000-0002-9939-4235 \\ Muş Alparslan Üniversitesi İslami İlimler Fakültesi \\ Temel İslam Bilimleri, Tasavvuf Ana Bilim Dalı \\ Muş/Türkiye
}

Atıf@ Yiğit, Mesut. "Son Dönem Hâlidî-Nakşî Şeyhlerinden Çelebi Süleyman Kaya Efendi'nin Tasavufî Düşüncesi”. Harran Üniversitesi Ilahiyat Fakültesi Dergisi 44 (Aralık, 2020): 125-141

Makale Bilgisi / Article Information

Makale Türü / Article Types : Araştırma Makalesi / Research Article

Geliş Tarihi / Received

: 26 Eylül 2020/ 26 September 2020

Kabul Tarihi / Accepted : : 26 Kasım 2020 / 26 November 2020

Yayın Tarihi / Published : : 15 Aralık 2020 / 15 December 2020

Sayı-Issue $\quad: 44$

Sayfa / Pages : : :125-141

DOI

: https://doi.org/10.30623/harranilahiyatdergisi.800628 


\section{Öz}

Son dönem Nakşî-Hâlidî geleneğinin şeyhlerinden Çelebi Süleyman Kaya Efendi, tasavvuf tarihinde müstesna bir yer işgal eden Cizre şehrinde doğmuştur. Irak Tavîle Dergâhı'nın NakşîtHâlidî pîr Şah Muhammed Ali Hüsameddin'in baş halifesi Seyyid Muhammed Kadri Hazîn'in önemli halifeleri arasında yer almıştır. İyi bir eğitim alan Çelebi Süleyman Efendi, uzun yıllar süren devlet memurluğu döneminde ve sonrasında irşat faaliyetlerini de kesintisiz sürdürmüştür. Hayatı boyunca sünnet-i seniyye'ye ittiba etmeye çalışmıştır. Diğer tasavvuf büyükleri gibi istikâmeti kerâmete tercih etmiştir. Ülkenin birçok yerinde yaptığı irşat çalışmaları neticesinde sayısız insana manevi rehberlik ve destekte bulunmuştur. Çelebi Süleyman Efendi, Nakşî-Hâlidî tarîkatının Cizre kolunun şeyhlerinden Şeyh Said Seyfeddîn'e ait Muhtasaru's-Sülûk ve'l-ihsân fî beyâni'l-Vusûl ilâ Meliki'lMülûk ve Tarîkatu'l-Hâcegân adlı eserin gün yüzüne çıkmasına vesile olmuştur. Nakşî-Hâlidî tarîkatının âdâb, erkân ve usullerinin anlatıldığı bu çok kıymetli kitabı akıcı bir üslup ile tercüme etmiştir. Kitaba gerekli açıklamalar ekleyerek içeriğini zenginleştirmiştir. Yine mürşidi Seyyid Muhammed Kadri Hazîn'e ait Dîvân-ı Irfân adlı eseri tercüme etmiştir. Kıymetli açıklamalar ilave etmek suretiyle eserdeki şiirlerde geçen tasavvuf literatürünün birçok teriminin anlaşılmasına vesile olmuştur. Tasavvufî düşünce sahasına önemli katkılar sunan bu iki eseri Gönül Sultanları ve Hak Sohbetleri adıyla bir kitapta toplamıştır. Bu çalışmada tercüme, şerh ve sohbetlerinden elde edilmiş dokümanların analizi yapılarak Çelebi Süleyman Efendi'nin tasavvufî düşünceleri ele alınacaktır.

Anahtar Kelimeler: Tasavvuf, Çelebi Süleyman Kaya, Gönül Sultanları ve Hak Sohbetleri, Nakşbendiyye, Mürşid, Hakikat, Kerâmet

\section{Abstract}

Çelebi Süleyman Kaya Efendi, one of the sheikhs of the late Naqshbandiyya tradition, was born in the city of Cizre, which has an exceptional place in the history of Sufism. He became one of the most important caliphs of Sayyid Muhammed Kadri, who was the chief caliph of the Nakşî-Halidi Pîri Shah Muhammed Ali Husameddin of the Iraqi Tavîle Lodge. For many years, Çelebi Süleyman Efendi, who had received a very good education, continued his teaching activities during and after his civil service period. Throughout his life, he endeavoured to apply Prophet's Sunnah into his life. Like many sufists, he preferred bein on the right pathway to performing miracle. Thanks to his teachings all over the country, he provided spiritual guidance and support for many people. Çelebi Süleyman Efendi was instrumental in the emergence of Muhtasaru's-Sülûk ve'l-ihsân fî beyâni'l-Vusûl ilâ Meliki'l-Mülûk and Tarîkatu'l-Hâcegân by the famous sheikh Said Seyfeddîn of the Cizre branch of the NakşîHâlidî order. He fluently translated this very precious book, in which the manners, principles and methods of the Nakşî-Hâlidî order are explained. He enriched the content by adding necessary annotations to the book. He also translated the work titled Dîvân-ı Irfân by his master Sayyid Muhammed Kadri Hazîn. By adding valuable annotations, he contributed greatly to understanding many terms of Sufi literature, present in the poems in the work. He 
collected these two works, which made important contributions to the field of sufi thought, into a book called Gönül Sultanları and Hak Sohbetleri. In this study, the sufi thoughts of Çelebi Süleyman Efendi will be examined by analyzing the documents obtained from some of his translations, commentaries and sermons.

Keywords: Sufism, Çelebi Süleyman Kaya, Gönül Sultanları ve Hak Sohbetleri, Naqshbandiyya, Master, Truth, Miracle

\section{Giriş}

Son dönem Nakşî-Hâlidî şeyhlerinden olan Çelebi Süleyman Kaya Efendi, Osmanlıdan sonra Cumhuriyet'in kurulduğu dönemde âlim ve tarikat ehliyle meşhur Cizre'de yetişmiştir. ${ }^{1}$ Medrese ve tekkelerinin çokluğuyla bilinen bu şehirde yaşayan insanlar az çok bu manevi atmosferden nasibini almıştır. ${ }^{2}$

$\mathrm{Hz}$. Ömer döneminde fethedildiğinden çok yakın zamanlara kadar İslam medeniyetinin ilim, kültür ve irfan merkezlerinden biri olan memleketi Cizre'de ${ }^{3}$ çok iyi bir medrese eğitimi aldığı tercüme, açıklama ve sohbetlerinden anlaşılmaktadır. Nakşî-Hâlidî geleneğinin ${ }^{4}$ tanınmış isimlerinden biri olan; ilmî, edebî ve tasavvufî birikimiyle de kendisinden sonra derin izler bırakan Seyyid Muhammed Kadri Hazîn (v. 1961)'in, irşad ve terbiye dairesine katılması Çelebi Süleyman Efendi'ye büyük kazanımlar sağlamıştır. ${ }^{5}$ Çelebi Süleyman Efendi bu büyük ummandan kana kana içmiş ilim ve irfan ile dolarak coşkun bir denize dönüşmüştür. ${ }^{6}$ Çelebi Süleyman Efendi vasıtasıyla Seyyid Muhammed Kadri Hazîn'i tanıyıp ona intisap eden ve sonrasında da halifeleri arasına giren Cemal

1 İslam tarihinde özel bir yeri olan Cizre tasavvuf tarihinde de önemli bir yer işgal etmektedir. Özellikle Nakşî-Hâlidî Mutasavvifların yoğunlukla bulunduğu bir yer olan Cizre'nin mutasavvıflarından bir kısmı şunlardır: Şeyh Abdurrahman Velî, Mevlânâ Şeyh Ahmed el-Cezerî, Şeyh Muhammed el-Gavvâs, Mevlânâ Şeyh Hâlid el-Cezerî, Şeyh Ömer Zengânî, Şeyh Muhammed Said Seyfeddîn, Şeyh Abdulhakim ed-Dîrşevî, Şeyh Muhammed Nûrî ed-Dirşevî, Molla Abdurrahman Hûserî, Şeyh Seyyid Muhammed Kadri Haşimî, Şeyh Said Seyda el-Cezerî v.d.

2 Cizre şehri, tarih boyunca büyük mutasavvıf ve alimler yetiştirmiştir. Bu aksiyoner alimler i̇slam dünyasına ve insanlığa çok önemli katkılarda bulunmuşlardır. Bu durumun oluşmasında medrese ve tekke birlikteliğini çok iyi sürdürebilen şehir yapısının katkısının çok olduğu düşünülebilir. Cizre'nin ilim ve kültür hayatına büyük etkileri olmuş ama günümüzde bu varlık ve etkisini kaybetmiş medreselerden bir kısmı şunlardır: Cizre Ulucami, Abdaliyye Medresesi, elMedresetu'I-Hamrâ, el-Medresetu's Süleymaniyye, el-Medresetü'l-Mecdiyye. Geniş bilgi için bkz. Abdullah Yaşın, Bütün Yönleriyle Cizre, (Basım yeri yok: Yücel Matbaacılık, 1983), 37-63.

3 Muhammed b. Ömer el-Vâkıdî, Tarîh Futûhi'l-Cezîreti ve'l-Hâbûri ve Diyarbekr ve'l-Irak, thk. Abdülaziz Feyyad Harfûş (Şam: Dâru'I-Beşâir Li't-Tabâ'ati ve'n-Neşri ve't-Tevzi', 1417/1996), 234 235.

4 Tarîkatın Pîri Mevlânâ Hâlid-i Bağdâdî'nin baş halifesi Şeyh Osman Siracuddîn et-Tavîlî́nin torunu Şah Muhammed Ali Hüsameddîn et-Tavîî́'dir.

5 Çelebi Süleyman Kaya Efendi, Seyyid Muhammed Kadri Hazîn'in irşad halkasına katılmasını şöyle değerlendirir: "Elhamdülillâh onun kısmeti olmuş biz mürîdlerin saadeti hiçbir şey ile ölçülemez." Bkz. suleymankaya-kds.com (ÇSK), (Erişim 4 Nisan 2020).

6 Çelebi Süleyman Kaya Efendi bir sohbetinde Seyyid Muhammed Kadri Hazîn'den en çok istifade edenin onun marifet deryasından ancak bir damla alabildiğini söylemiştir. M. A. Kolacı, Kişisel iletişim, 20 Şubat 2019. 
Doğramaci ${ }^{7}$, ilk görüşmesinde Çelebi Süleyman Kaya Efendi'nin cazibesine kapıldığını dile getirmiştir. Kendisi birçok tekke ve şeyh gördüğünü hatta dedesinden de tarîkat dersi aldığını ama buna rağmen aradığını bu tanışmadan sonra bulduğunu ifade etmiştir. ${ }^{8}$

Çelebi Süleyman Efendi, Nakşî-Hâlidî yolunun feyizleriyle kemâlât merdivenini tırmanmaya başlamış, ihlâsıyla şeyhinin iltifatlarına nail olmuştur. Nakşî-Hâlidî yolunu başta i̇stanbul, Ankara, İzmir, Adana, İskenderun, Gaziantep, Ş. Urfa ve Elazığ olmak üzere Anadolu'nun birçok yerinde yaymaya çalışmıştır. ${ }^{9}$ Aşağıdaki rubaide şeyhi Seyyid Muhammed Kadri Hazîn onu paha biçilemez bir mücevher ve lekesiz bir ayine olarak nitelendirmiştir. ${ }^{10}$

"Süleyman bî pahadır dürrü pür tâm,

Hakikat nevcivandır bedri Hisâm

Hazînin hizmetinde çok müheyyadır bu dili kâm,

Hazîn'indir Hazîn'indir güzel cam "

Yine Seyyid Muhammed Kadri Hazîn, Çelebi Süleyman Kaya Efendi'nin kendi ehlinden olduğunu ve iki dünyada da refiki ve habibi olduğunu bildirerek kendisine şöyle iltifat etmiş̧ir: ${ }^{11}$

Süleymanım çe Süleyman ehli âlimdir yakîn

Nûri evlâdi Muhammed âşikardır der cebîn

Nûri Kadridir yüzünde ey civanı sâfi dil

Farkı yokdur hâ Aliyyü ve hâ Hazîn

Ey Süleymanı Hazîn vey civanı pâki dîn

Vey refik u her du dînu vey habibi kadriddîn

1. Çelebi Süleyman Kaya'nın Hayatı ve Eserleri

\section{1. Adı, Ailesi, Tahsil Hayatı ve Çocukları}

1919 yılında Cizre'de doğdu. Babası şehrin eşrafından Abdurrahman Efendi olup annesinin adı Medine Hanım'dır. İlköğrenimini Cizre'de tamamladıktan sonra Lise tahsili için Diyarbakır'a gitti. ${ }^{12}$ Zahiri ilimleri kimin yanında tahsil ettiği bilinmemektedir. Ancak küçüklüğünden beri sohbetlerine devam ettiği Seyvid Muhammed Kadri Hazîn'den zahiri ilimleri de tahsil ettiği sanılmaktadır. ${ }^{13}$

7 Doğramacızade Ali Sami Paşa oğlu, Prof. Dr. İhsan Doğramacı'nın kardeşidir.

8 Cemal Doğramacı, Kardeşim Süleyman Kaya'ya ithaf, (Ankara, ts.), 20-21.

9 Doğramacı, Kardeşim Süleyman Kaya'ya ithaf, 23-24.

10 suleymankaya-kds.com (ÇSK), (Erişim 26 Mart 2020), Doğramacı, Kardeşim Süleyman Kaya'ya ithaf, 26.

11 suleymankaya-kds.com (ÇSK), (Erişim 26 Mart 2020), Doğramacı, Kardeşim Süleyman Kaya'ya ithaf, 26.

121970 yılında Cizre lisesi açılana kadar Cizre'de lise tahsilini almak isteyenler civar şehirlerdeki okullarda tahsillerini sürdürmüşlerdir.

13 M. Kaya, Kişisel İletişim, 12 Şubat 2019. 
Cemal Doğramacı, Çelebi Süleyman Kaya Efendi'yi ilahî hakikatleri ve Rabbânî mevhibeleri yorumlayabilecek ilme sahip bir ârif-i billâh olarak tanıtmaktadır. Belirttiğine göre üslubu etkileyici olup dinleyicilerinin hemen dikkatini çekmekte idi. Sohbetlerini icra ederken geniş bir malumata sahip olduğundan yaptığı yorumlar meclisin şevk ve heyecanını diri tutmakta idi. Yine Çelebi Süleyman Kaya Efendi'nin ilmine ve kabiliyetine işaret etmek üzere şöyle demiştir: "Hizmet aşkı, sadakatı, mahviyet ve teslimiyeti sayesinde Seyyid Kadrî Hz.lerinin tam meşrebinde ve halâvetinde yetişen bu zât, aynı zamanda gerek Sultanımızın ve gerekse meşhur Ahmed Cezerî Hz.lerinin divanlarının hemen bütün kısımlarının inceliklerine tamamen vakıf ve o manevî halleri yaşar durumda sohbetler yapmakta, kuvvetli hafizaları sayesinde Hazretten dinlediklerini de beyan ederek huzurlarında bulunanları hayran bırakmaktadırlar. Bu hal, her halife ve veliye nasib değildir. Bu yüzden de Ankara'da olgun zatlarla yapılan meclis ve toplantılarında her seviyede herkese hitab edecek kabiliyeti olması hasebiyle sohbetleri anlatılmakta ve seyahate çıktıklarında aranmaktadırlar. ${ }^{14}$

Çelebi Süleyman Kaya Efendi 1942 yılında TCDD bünyesinde işe girerek memuriyet hayatına adım atmıştır. Türkiye'nin değişik yerlerinde memur olarak bulunduğu sırada kendisine verilen hizmetleri üstün bir gayretle yerine getirmiş aynı zamanda insanların maddi ve manevi ihtiyaçları için çalışmayı görev bilmiştir. En son 1974 yılında müfettiş olarak görev yaptığı TCDD'den emekliye ayrılışstır. Şükran ve Ayşe isminde iki kız, Mehmet Ali $^{15}$ isminde de bir erkek çocuğu olmuştur. ${ }^{16}$

\section{2. Intisabı}

İlkokul çağında bir öğrenci iken tanıştığı Nakşî-Hâlidî tarîkatının tanınmış mürşidlerinden Cizreli Seyyid Muhammed Kadri Hazîn'e intisap eder. ${ }^{17}$ Bir yandan okul tahsilini sürdürürken diğer yandan da şeyhinin sohbetlerine devam eder. Tasavvufî açıdan kemale ulaşması için Şeyhi tarafından itina ile yetiştirilir. Kendisini çok seven mürşidi Seyyid Muhammed Kadri Hazîn ona "Çelebi" ${ }^{18}$ lakabını verir. Şeyhinin yanında seyr u sülûk eğitimini tamamlar en sonunda hilafet ile taltif edilir. ${ }^{19}$

Seyyid Muhammed Kadri Hazîn tarafından kendisine halifelik verilmesini şöyle zikreder:20 "Hemen her sene istanbul'dan, Ağapınar'dan, Geyve'den $\mathrm{Hz}$.

14 Doğramacı, Kardeşim Süleyman Kaya'ya ithaf, 19-25.

15 Halen irşat vazifesini yürütmektedir.

16 Mehmet Kaya, Doğramacı, Kardeşim Süleyman Kaya'ya ithaf, 22.

1712 yaşında Seyyid Muhammed Kadri Hazîn'e intisap ettiğini belirtir. Bkz. Doğramacı, Kardeşim Süleyman Kaya'ya ithaf, 35.

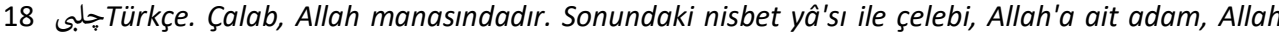
adamı demektir. Kibar, zarif kimselere de "çelebi adam" denir. XVII. Yüzyıl'ın sonlarına kadar bilgin ve soylu kimseler için, yine bu unvan kullanılmıştır. Bkz. Ethem Cebecioğlu, Tasavvuf Terimleri ve Deyimleri Sözlüğü, (İstanbul, Ağaç Kitabevi Yayınları, 2009), 141.

19 Şeyhi Seyyid Muhammed Kadri Hazîn Efendi Çelebi Süleyman Efendi'ye verilen icâzette şöyle yazılmasını emretmişlerdir: "... Süleyman Kaya'yı, Nakşi ve Kadiri Tarîkatlarından mezun ettim. Benim halifemdir. Onun hatme-i şerifi, benim hatmemdir, onun zikir halkası, benim zikir halkamdır..." Bkz. suleymankaya-kds.com (ÇSK), (Erişim 10 Nisan 2020).

20 Bkz. suleymankaya-kds.com (ÇSK), (Erişim 11 Nisan 2020). 
Şeyh'in ziyaretine gitmeden duramazdım. Maraş'tan ziyaretine gitmiştim. Lütufları güneş gibi aşikârdı. Bir sabah "Sana hilafet vereceğim" buyurdu. Ben, böyle bir nimetin ne kadar büyük olduğunu, kendimi çok aciz görmekle, fakat onun lütuflarının daha büyük olduğu, nazarları önünde hiçbir şeyin zor olmadığını biliyordum. Ertesi gün ziyaretine gittiğimde mübarek yüzü bir Muhammedî gül gibi neşeli idi. Merhaba vererek iltifat etti. Buyurdu ki: "Akşam senin için hiç yatmadım. istedim... Çok lütfettiler. Öyle ki istediğimden çok daha fazla ikram ettiler. Ben de pek çok memnun ve mesrur oldum". Ben, fakirane arz ettim ki: "Hep sizin nazar ve lütuflarınızdır. Kerem, Cedlerinizin, Şahınızın ve sizin şiarıdır." Ertesi sabah yine huzur-ı saadete vardığımda yine gül gibi açılan o mübarek güzel yüzüyle iltifatlarını devam ettirdiler. Buyurdular ki: "Evvelki akşam o kadar lütfetmişlerdi ki ben bile doymuştum, yani kâfi bulmuştum. Fakat bu gece de lütuflar devam etti. Elhamdülillah pek çok mutluyum". Şeyh Şurahbil'e emir vererek icâzetimin şu şekilde yazılmasını buyurdular: "... Süleyman Kaya'yı, Nakşi ve Kadiri Tarîkatlarından mezun ettim. Benim halifemdir. Onun hatme-i şerifi, benim hatmemdir, onun zikir halkası, benim zikir halkamdır..."

Çelebi Süleyman Efendi'ye göre bağlı bulunduğu tarîkat Pîrleri Şâh Muhammed Ali Hüsameddin et-Tavîî (v. 1939) ve Seyyid Muhammed Kadri Hazîn'in velayette makamlarından daha üstün bir makam yoktur. Intisap ettiği günden vefatına kadar bağlı bulunduğu tarîkatı yaymaya çalışmış bu uğurda birçok fedakârlık göstermiştir. Bu gayreti ve çalışması neticesinde sayısız Müslümanın takva ve istikâmet dairesine girmesine birçok Hristiyan'ın da İslam ile müşerref olmasına vesile olmuştur. ${ }^{21}$

\section{3. Tarîkat Silsilesi}

Çelebi Süleyman Kaya Efendi'nin hilafet aldığı şeyhi Seyyid Muhammed Kadri Hazîn'e ulaşan tarîkat silsilesi şu şekildedir:22

Hz. Muhammed Mustafa (s.a.v.)

Hz. Ebû Bekir es-Sıddîk (r.a.)

Hz. Selmân-ı Fârisî (r.a.)

Kasım b. Muhammed b. Ebî Bekir es-Sıddîk (r.a.) (v. 107/725 [?])

Ca'fer es-Sâdık (r.a.) (v. 138/755-56 [?])

Ebû Yezîd Tayfûr Bistâmî (v. 234/848 [?])

Ebü'I Hasen el-Harakânî (v. 425/1033)

Ebû Ali el-Farmedî (v. 477/1084)

Hâce Yusuf el-Hemedânî (v. 535/1140)

Hâce Abdulhâlik-i Gucdüvânî (v. 575/1179)

Hâce Ârif Rîvegerî (v. 634/1236-37)

Hâce Mahmud encîr Fağnevî (v. 715/1315-16 [?])

21 Muhammed Ali Kolacı, 1974 Adana, 20 Şubat 2019; Çelebi Süleyman Kaya, “1B”, (1975), 00:08:3000:13:15.

22 Çelebi Süleyman Kaya, Gönül Sultanları ve Hak Sohbetleri (Ankara: Kültür Ofset, 1996), 124-125. 
Azîzân Hâce Ali Râmitenî (v. 715/1315)

Hâce Muhammed Baba es-Semmâsî (v. 736/1335-36 [?])

Seyyid Emîr Külâl (v. 772/1370)

Şâh-ı Nakşibend Hâce Muhammed Bahâuddîn el-Buhârî (v. 791/1389)

Hâce Muhammed Alâüddîn Attâr (v. 802/1400)

Hâce Ya'kûb el-Çerhî el-Hisârî (v. 851/1447)

Hâce Ubeydullâh Ahrâr (v. 895/1490)

Hâce Muhammed ez-Zâhid (v. 936/1529)

Hâce Muhammed Dervîş(v. 970/1562)

Mevlânâ Hâcegî Emkenegî es-Semerkandî (v. 1008/1599)

Hâce Muhammed Bâkî-Billâh (v. 1012/1603)

İmâm Rabbânî Ahmed es-Serhendî el-Fârûkî (v. 1034/1624)

Şeyh Muhammed Ma'sûm el-Fârûkî (v. 1079/1668)

Şeyh Seyfüddin el-Fârûkî (v. 1096/1684)

Seyyid Nûr Muhammed Bedevânî (v. 1135/1723)

Cân-ı Cânân Şâh Mazhar (v. 1195/1781)

Şâh Abdullah ed-Dehlevî (v. 1240/1824)

Mevlânâ Hâlid-i Bağdâdî (v. 1242/1827)

Şeyh Osman Siracüddin et-Tavîî (v. 1867)

Şeyh Muhammed Behaeddin-i Evvel et-Tavîîi (v. 1881)

Şâh Muhammed Ali Hüsameddin et-Tavîî (v. 1939)

Şeyh Muhammed Saîd Seyfeddîn (v. 1916)

Şeyh Seyyid Muhammed Kadri Hazîn (v. 1961)

\section{4. Eserleri}

Çelebi Süleyman Efendi, Şeyh-i Meczûb Şeyh Muhammed Said Seyfeddîn'e ait Arapça kaleme alınan Muhtasaru's-Sülûk ve'l-ihsân fî Beyâni'I-Vusûl ilâ Meliki'lMülûk ve Tarîkatu'l-Hâcegân ${ }^{23}$ adlı eseri ve Seyyid Muhammed Kadri Hazîn'e ait Kürtçe kaleme alınmış Dîvân-ı Irffân Hayreti Hayrân ${ }^{24}$ adlı eseri Türkçeye tercüme etmiştir. Bu iki kıymetli esere aynı zamanda değerli açıklamalar ekleyerek ilgililerin istifade etmesini kolaylaştırmıştır. Daha sonra bu iki eseri bir araya getirerek Gönül Sultanları ve Hak Sohbetleri adıyla yayımlamıştır. ${ }^{25}$

\section{5. Kerâmetleri}

Kerâmet; peygamberlik iddiası gütmeksizin istikâmet ve takva sahibi bir zâttan hârikulâde hadiselerin zuhur etmesidir. ${ }^{26}$ Çelebi Süleyman Efendi'ye göre

23 Şeyh-i Meczub Şeyh Muhammed Said Seyfeddin tarafından Arapça kaleme alınan bu eser NakşîHâlidî yolunun usul ve edeplerini öğretmekte ayrıca mürşidlerini tanıtmaktadır.

24 Şeyh Seyyid Muhammed Kadri Hazîn tarafından yazılan ve yaklaşık iki bin beyitten oluşan şiirler vefatından sonra Dîvân-ı İrfân Hayret-i Hayrân adı verilen eserde toplanmıştır.

25 Eserin 1977 yılında ilk baskısı yapılmış daha sonra defalarca yayımlanmıştır.

26 İmam Abdülkerîm el-Kuşeyrî, er-Risâletü'l-Kuşeyriyye, thk. Ahmed Hâşim es-Sülemî, (Beyrut: Dâru'I-Kutubü'l-illmiyye 1434/2013) 379; Ali b. Osman Cüllâbî Hücvirî,, Keşfü'l-Mahcûb (Hakikat 
mümin için esas olan husus Yüce Allah'ın rızasına uygun bir hayat yaşayabilmesi olup kerâmet peşinde koşmamasıdır. Eshâb-ı Kiram da Peygamber Efendimiz (s.a.v.)'den böyle bir talepte bulunmamıştır. ${ }^{27}$ Ancak kerâmetlerin Cenab-ı Hakk'ın veli kullarına $\mathrm{Hz}$. Peygambere (s.a.v.) ittibalarından dolayı verildiğini ve hak olduğunu ifade eder. ${ }^{28}$ Çelebi Süleyman Efendi şeyhinden naklettiği bir bilgi ile tarîkatın esasının ve gayesinin çok yüksek olduğunu bunu kerâmete irca etmenin basit düşeceğini bildirmektedir. ${ }^{29}$

Sevenleri, Çelebi Süleyman Efendi'nin çoğu kez mürîdlerinin merak ettikleri veya sormak istedikleri bir hadiseyi daha onlar sormadan cevaplandırdığını, böylece kalplerinden geçenleri keşfettiğini bildirmiştir. Yine onun duasının bereketiyle birçok hasta şifa bulmuştur. Çelebi Süleyman Efendi'nin kendisinden zuhur eden hârikulâde olayları çok mütevazi bir kişilik olduğundan dolayı devamlı mürşidlerinin bereketine dayandırdığı ifade edilmektedir. Yine sevenlerinin anlattıklarına göre Çelebi Süleyman Efendi hayatını en büyük kerâmet sayılan istikâmet üzere geçirmiş, sünnet-i seniyyeye harfi harfine uymaya gayret göstermiştir. Zaten kendisi de sohbetlerinde sair sûfîler gibi bu hususa daha çok önem atfetmiştir. ${ }^{30}$

\section{6. Vefatı}

Şeyhi Seyyid Muhammed Kadri Hazîn'in sevgisine ve iltifatlarına mazhar olan Çelebi Süleyman Efendi 2005 senesinde Hakk'ın rahmetine kavuşmuştur. Çok sevdiği ve her anıldığında özlemiyle gözlerinden yaşlar boşandığı şeyhinin ve evlatlarının yanına defnedilmesi, hayattayken en büyük arzusuydu. Neticede bu arzusuna kavuşmuştur. Sadece Seyyid Muhammed Kadri Hazîn'in çocuklarının defnedildiği türbeye kendisi de defnedilmiştir. Berzah âleminde de hasretiyle yandığı şeyhinin yanında bulunmuştur. Seyyid Muhammed Kadri Hazîn, Çelebi Süleyman Efendi için şunları söylemiştir: ${ }^{31}$

\section{Ey Süleyman Çelebî vey Çelebî Rûh Çelebî, \\ Der dili men tû hebi hâdimi evlâdi nebi ya Çelebî, \\ (Gönlümün içindesin, Ehl-i beytin hizmetkârı Çelebî) \\ Be hisâb ehli mebi ya Çelebî Rûh Çelebî, \\ (Hesapsız bizim ehlimizdensin ey Çelebî, Rûh Çelebî) \\ Veki Selmân-i mebi ya Çelebî Rûh Çelebî,}

Bilgisi), çev. Süleyman Uludağ (İstanbul: Dergah Yayınları, 2018), 281; Ali b. Muhammed es-Seyyid eş-Şerif el-Cürcânî, Mu'cemu't-Ta'rîfât, thk. Muhammed Sıddîk el-Minşâvî, (Kahire, Dâru'l-Fadîle, ts.), 207; Ferîdüddîn Attâr, Tezkiretü'l-Evliyâ, çev. Süleyman Uludağ (İstanbul: Semerkand Yayınları, 2018), 681.

27 Çelebi Süleyman Kaya, Sohbetler, haz. Sabiha Aşan, (Ankara ts.) 91.

28 Kaya, Sohbetler, 96.

29 Kaya, Sohbetler, 13.

30 Kaya, Gönül Sultanları ve Hak Sohbetleri, 11Çankırı Postası, (ÇP), "Kürşad Erenbilge Mülakatı", (Erişim 5 Ocak 2020).

31 suleymankaya-kds.com (ÇSK), (Erişim 27 Mart 2020), Doğramacı, Kardeşim Süleyman Kaya'ya ithaf, 26. 
(Selman'ımız gibisin, ey Çelebî, Rûh Çelebî)

Şeb u rûz zikri mebi ya Çelebî Rûh Çelebî,

(Gece gündüz hatırımızdasın ey Çelebî, Rûh Çelebî)

\section{2. Çelebi Süleyman Kaya'nın Tasavvufí Düşüncesi}

\section{1. Şeriata İttiba}

Kur'an-ı Kerîm'de ve Peygamber Efendimiz'in hayatında müminler için dünyada düzen ve huzuru sağlayacak ahirette de ebedi saadeti temin edecek kurallar vardır. Mümin bir bireyin hayat yolculuğunda emniyetle yol kat etmesi için bu kuralların ve edeplerin yaşamının her aşamasında yer alması gerekmektedir. Çelebi Süleyman Kaya Efendi de uyulacak en güzel yolun Kur'an-ı Kerîm, şerîat-ı garrâ ve ahlâk-ı Muhammediye olduğunu dile getirmektedir. Allah'u Teâlâ'nın emirlerine ve Peygamber Efendimiz'in (s.a.v.) Sünnetine uymayı da özellikle sâlik için elzem görmektedir. Yine ona göre şerîat-ı garrâ'ya kâmil manada uyan sûfîler mertebe açısından daha yüksektedirler. Sahv halini sekr halinden de daha üstün tutmaktadır. Bunun için eşsiz bir makam ve vuslat sahibi olarak nitelediği şeyhinin büyüklüğüne, aynı zamanda şerîat-ı garrâ'dan hiç şaşmadan bir hayat sürmesini delil olarak getirmektedir. ${ }^{32}$ Nitekim İmam Rabbânî de Kur'an ve Sünnete tabi olmadıkça manevi hallerin hiçbir kıymeti olmadığını bildirmektedir. ${ }^{33}$

Çelebi Süleyman Kaya Efendi gerek Şeyh-i Meczûb Şeyh Muhammed Said Seyfeddîn'e ait Muhtasaru's-Sülûk ve'l-ihsân adlı kitaba yaptığı yorumlarda gerekse de mürşidi Seyyid Muhammed Kadri Hazîn'in şiirlerine yaptığı yorumlarda istikâmetten ayrılmamayı Yüce Allah'tan talep etmiştir. Bu da onun tarîkatın şeriatsız olamayacağı Kur'an-ı Kerim ve Sünnet-i seniyyeye uymadan kâmil bir mümin olunamayacağı inancından kaynaklanmaktadır. ${ }^{34}$ Seyr u sülûktan maksat olan vuslatın elde edilebilmesi içinde şöyle demektedir: "illa ki onun lûtfu, Hazreti Peygamber Efendimizin Aleyhisselâtı Vesselâm'ın himmeti, rehberliği, usulü, sünneti, mutlak surette şarttır. Pîran-ı izamlarda bu yolun birer memurudurlar."135

\section{2. Âdâba Riâyet}

Çelebi Süleyman Efendi Rabbânî lütufların ve seyr u sülûk'un emniyetle devam etmesi için mürşidin belirlediği edeplere riayeti şart görmektedir. "Kalbi uyanık, usûl ile giden mürîde ne lütuflar vardır!"36 Yine Nakşî-Halidî usulüne göre tarîkat pîrleri tarafından verilen ve "Hatm-i Hâcegân" ${ }^{37}$ da denilen zikir usulünün değiştirilmemesi gerektiği, bunda nice sırların olduğunu ifade etmektedir. "Bu zikirler ve âdâblar büyük bir sır olup, aynısının değiştirilmeden yapılması

32 Kaya, Gönül Sultanları ve Hak Sohbetleri, 363; Kaya, Sohbetler, 233-234

33 İmâm-ı Rabbânî, Ahmed Fârûkî Serhendî, Mektûbât-ı Rabbânî, çev. Abdülkadir Akçiçek, (ístanbul: Çelik Yayınları, 2011) 1:236.

34 Kaya, Gönül Sultanları ve Hak Sohbetleri, 64,117.

35 Kaya, Sohbetler, 7.

36 Kaya, Gönül Sultanları ve Hak Sohbetleri, 45.

37 Hatm-i Hâcegân: "Nakşibendiyye tarikatının özellikle Hâlidiyye kolunda bazı sûrelerin bir tertib üzere okunması ve belli miktarda zikir çekilerek yapılan uygulama." Bkz. Cebecioğlu, Tasavvuf Terimleri ve Deyimleri Sözlüğü, 256; Reşat Öngören, "Hatm-i Hâcegân", Türkiye Diyanet Vakfı islâm Ansiklopedisi (İstanbul: TDV Yayınları, 1997), 16/476. 
lâzımdır." ${ }^{\prime 38}$ Imam Rabbânî (v. 1034/1624)'de bu yolda âdâba riayet etmenin zaruri olduğunu, esas kavuşturucu olanın tarîkat âdâb ve usulüne uygun hareketler olduğunu beyan etmektedir. Bu minvalde şu şekilde tavsiyeleri vardır: "Şeyhinin harekâtına ve sekenâtına itiraz için, nefsine bir itiraz yeri asla bırakmamalıdır. Eğer itiraz, bir hardal tanesi kadar olsa, bu itirazın mahrumiyetten başka bir neticesi olmaz. Insanların en şakisi ve saadetten en uzak olanları, bu evliya taifesini ayıplı görenlerdir. Bu gibi büyük belâlardan Allah-ü Taâlâ, bizi korusun."139 Çelebi Süleyman Efendi, hakikî bir mürşidin elinde tarîkatta sülûk eden mürîde vuslat ve kavuşmanın husule gelmemesinin nedenini âdâb, erkân ve usulleri takip etmemesine bağlamaktadır. ${ }^{40}$

\section{3. Hizmet}

Çelebi Süleyman Efendi'ye göre tarîkata intisap eden birisi için en büyük lütuf ve terakki vesilesi hizmete sarılmasıdır. Çelebi Süleyman Efendi, Hak dostu bir mürşidin sohbetinin paha biçilmez bir Hazîne olduğunu, ölmeden tasarruf sahibi bir velinin hizmetine girip tavsiyelerine uyulması gerektiğini, bunun da Cenab-ı Hakk'a ulaştıran en kısa yol olduğunu şu sözleriyle ifade etmektedir: ${ }^{41}$ "Allah ve Resûl'ün yanında kıymetli mümin! Kıymetini idrak ederek, daha bu dünyadan çıkmadan, ilahi terbiye yolunda çok çalış! Allah'ın kudretiyle tasarruf eden evliyâyı sev! Bil ki bu, Hz. Resûl'ün en öz ve has ulaştırıcı yoludur. Evliyâya hizmet ile muhabbet ile ve rabıtasındaki esrar ile Mevla'nı bulmaya çalıș!"

Çelebi Süleyman Efendi samimiyetle bağlanmış olduğu tarikatın Pîrlerini manevî alemde tasarruf sahibi veliler olarak gördüğünü, onların dergâhına candan hizmet ettiğini ve onların eşiğinden ayrılmayacağını şu dizelerle vurgulamaktadır: ${ }^{42}$

"Bir lütfü ilâhî âleme merhamet

Âlem devrinde buldu yüksek saadet

Tarikinde bırakmadı mürîdane zahmet

Her kim dese YA ALi hazırdır himmet

Kul Süleyman şaha candan eder hizmet

Yüzüm eşikte geçse de yüz klyamet"

\section{4. Mürîd-Mürşid ilişkisi}

Çelebi Süleyman Efendi mürşitsiz vuslat olamayacağını, yolun ise tehlikelerle dolu olduğunu ifade etmektedir. Zahiri ilimlerde âlim olanların da kemâlâta ulaşabilmesi için mutlaka bir mürşid-i kâmilin gözetiminde seyr u sülûk eğitiminden geçmesi gerektiğine inanmaktadır. Bu hususta şöyle söylemektedir: ${ }^{43}$

38 Kaya, Gönül Sultanları ve Hak Sohbetleri, 117.

39 İmâm-ı Rabbânî, Mektûbât-ı Rabbânî, 1: 584

40 Kaya, Sohbetler, 225.

41 Kaya, Gönül Sultanları ve Hak Sohbetleri, 15.

42 Kaya, Gönül Sultanları ve Hak Sohbetleri, 185.; Cemal Doğramacı da Çelebi Süleyman Kaya Efendi'yi aşk ve fedakârlıkta sınırsız bir hizmet eri olarak tavsif etmiştir. Bkz. Doğramacı, Kardeşim Süleyman Kaya'ya ithaf, 26.

43 Kaya, Gönül Sultanları ve Hak Sohbetleri, 15. 
"Arifler Sultanı Hz. Beyâzid-i Bistâmî (v. 234/848 [?]): " Şeyhi olmayanın şeyhi şeytandır." Hakikat sözünü unutma! Unutma ki, azamet ve celâdetinin sonu olmayan Allah'u Teâlâ'nın huzûruna vasıtasız ve kolay gidilmez. Ihsan Yolu'nda belirtildiği gibi, her dört mezhebin büyük müctehidleri, zahir ilimde deniz gibi olmuşlar, fakat kemâlleri, tarikat-i aliyeye intisap etmekle tamamlanmıştır. Sultan'l-Ulema Bahauddin'in (v. 628/1231) oğlu ve zahirî ilimlerin sultanı $\mathrm{Hz}$. Mevlânâ Celâleddin-i Rûmî (v. 672/1273) nasıl her şeyi bırakıp, bir derviş olan Şems-i Tebrîzîye (ö. 645/1247 [?]) tutuldu; hakîkî kemâlâtı onunla buldu ve dedi ki: "Hamdım. Piştim. Yandım." Ona göre Yüce Allah, seçtiği bir peygamberi kendisi ile insanlar arasında vasıta kıldığı gibi mürşid-i kâmili de kendisi ile mürîdleri arasında vasıta kılmıştır. ${ }^{44}$

Çelebi Süleyman Efendi, kesiksiz bir silsileye bağlı bir şeyhe intisap eden mürîdin rûhunun kâmil şeyhin nûruna bağlandığını söylemektedir. Mürîd elfâz-ı küfür söylediğinde veya büyük günah işlediğinde şeyhinin onu terk edeceğini, onun nûrlu kandilinden ayrılacağını ifade eder. Eğer mürîd işlediği günahtan pişman olur ve tövbe ederse affedilir. Yalnız işlediği hatada ısrar ederse artık tarîkattan bir hissesi kalmaz ve tardedilir. ${ }^{45}$ Çelebi Süleyman Efendi, mürîd-mürşid ilişkisinde mürşidin kemâlât sahibi, irşada yetkili bir ârif-i billâh olması gerektiği üzerinde durmaktadır. Mürşidin ehliyet sahibi olmadıktan sonra mürîdlerinin sayıca çokluğunun Allah (c.c.) katında bir şey ifade etmeyeceğini kendi mürşidinden nakillerle anlatmaktadır. Çelebi Süleyman Efendi bir mürîd olarak müşahedelerine göre şeyhi Seyyid Muhammed Kadri Hazîn tarîkat basamaklarının en zirvesinde olan zâtlardan birisidir. Ona göre mürşidi, Hz. Peygamber (s.a.v.)'den gelen feyizlere en kâmil manada varis olan bir Allah dostuydu. Mürşidini tarif ederken de onun şu beyitlerini misal vererek anlatır: ${ }^{46}$

"Sâkîye havdım bıtacu izzu cahe be misâl

Vârise şahe Hüseynim canım hem cananeyim"

(Hz. Resûl havuzunun sakisiyim. Misli görülmemiş yüksek bir makâm ve taç ile

Şâh-ı Hüseyin'e varis oldum, sevenim hem de sevilenim)

Çelebi Süleyman Efendi'nin açıklama ve yorumlarının satır aralarında bir mürşid-i kâmilin özelliklerini verdiği görülür. Devamlı bir surette de hakiki bir mürşid-i kâmilin terbiyesinin altına girilmesinin lüzumunu işler. Çünkü Çelebi Süleyman Efendi'ye göre bir mürşidi kâmilin gözetimine girmek Allah'a (c.c.) vuslatı sağlayan en önemli vesilelerin başında gelmektedir. Mürşidinden söz ederken ona olan sarsılmaz bağlılığı ve sevgisi kendini hemen hissettirmektedir. Derin bir vecd ile gezdiği ve gördüğü tüm yerlerde onun bir benzeri ile karşılaşmadığını aktarmaktadır. Söylediğine göre mürşidinin saadet meclisine en dertli ve hüzünlü insanlar bile gelse dertlerini unutuverirdi. Şeyhi, Seyyid Muhammed Kadri Hazîn'in tüm hareketlerinde Peygamber Efendimiz (s.a.v.)'i

44 Kaya, Sohbetler, 144.

46 Kaya, Gönül Sultanları ve Hak Sohbetleri, 7; ÇSK), "Sultan Seyyid Kadri Mevlâna Hazîn". 
takip etmeye çalışığını, Sünnet-i seniyyeye azami derecede dikkat gösterdiğini bildirmektedir. ${ }^{47}$

\section{5. Tecellî}

Sûfîlere göre tecellî, "gayb aleminden kalbe görünen nûrlardır." ${ }^{48}$ Onlar, tecellînin devamlı olanına kıymet vermiş geçici olanına itibar etmemişlerdir. ${ }^{49}$ Çelebi Süleyman Efendi, tecellî mertebelerinin üç şekilde olduğunu söylemektedir: ${ }^{50}$ Yüce Allah'ın zatı ile tecelli etmesi, esmâ ve sıfatı ile tecelli etmesi veya insan-ı kâmilde tecellî etmesidir. ${ }^{51}$ Çelebi Süleyman Efendi'ye göre feyz ve tecellîde kâmil olanlar kalbi hastalıklarını tedavi etmiş ve keşfi Rabbânîye açık hale gelmiştir. ${ }^{52}$

Çelebi Süleyman Efendi sûfînin seyr u sülûk mertebelerini aşarken Makâm-ı Musevî ${ }^{53}$ tecellîsi ile yol almasının sâlik için çok zorlu olduğunu ifade etmektedir. Çünkü bu makamda olanlar çok yakıcı bir tecellî ile karşılaşırlar bazen de aklî muhakemelerini kaybedebilmektedirler. Zahiri suretler tecellîsi ile görünen sureti Allah zannederek bazı şatahatlar söylerler. Fakat en sonunda Allah'u Teâla lütfederek onları bu halden kurtarır şeriat-ı garrâya dönmelerine yardımcı olur. Çelebi Süleyman Efendi bu duruma Hallâc-ı Mansûr (v. 309/922) ve Bayezîd Bistâmî́yi örnek vermektedir. ${ }^{54}$

\section{6. Hakikat}

Çelebi Süleyman Efendi “Hakikati gören, hayali, lüzumsuzluğundan dolayı atar" sözüyle görüyormuşçasına kulluk yapanların gösterişe değer vermeyeceğini belirtir. Bununla hakikate ulaşma çabasının önemini vurgulamaktadır. ${ }^{55}$

Çelebi Süleyman Efendi'ye göre şuhudî iman şeriatın esas gayesidir. Bu da perdelerin ardında olan gizli manayı müşahede etmektir. Yani hakikat ilmini idrak edebilmektir. Hakikat erbabı olarak gördüğü Mevlânâ Celaleddin Rûmî için de şu ifadeleri kullanmaktadır: ${ }^{56} \mathrm{~Hz}$. Mevlâna Celâleddin'den (Kds) mezhebini sormuşlar, "Allah" demiş. Evet her emir ve isteği Allah'tan doğrudan doğruya alan, zaten başka bir şekilde hareket edemez ki. Şeriatın nakli ve hem de hakikatine ermişler."

47 Kaya, Gönül Sultanları ve Hak Sohbetleri, 6,7,17,18.

48 Abdurrezzak el-Kâşânî, Mu'cemu Istılahâti's-Sûfiyye, thk. Abdulâl Şâhin, (Kahire: Dâru'I-Menâr, 1992), 173; Cürcânî, Mu'cemu't-Ta'rîfât, 46.

49 Mesut Yiğit, Yusuf en-Nebhânî ve Şiirindeki Tasavvufî Unsurlar (Ankara: Fecr Yayınları, 2020$), 168$.

50 Sehl b. Abdullah et-Tüsteri tecellinin üç hâlinin olduğunu söylemektedir: "Zâtın tecellisi: Mükâşefe, Zâtın sıfatının tecellisi: Nûr mahalli, Zâtın hükmünün tecellisi: Ahiret ve oradaki haller." Geniş bilgi için bkz. Ebubekir Muhammed Kelâbâzî, Doğuş Devrinde Tasavvuf (Ta'arruf), çev. Süleyman Uludağ (İstanbul: Dergâh Yayınları, 2019), 197-200.

51 Kaya, Gönül Sultanları ve Hak Sohbetleri, 175.

52 Kaya, Gönül Sultanları ve Hak Sohbetleri, 400-401.

53 “Hz. Musa'nın (a.s.) makamından feyiz almış, onun huyunda ve meşrebinde manasındadır." Geniş bilgi için bkz. Hücvirî,, Keşfü'l-Mahcûb, 430-431; Süleyman Uludağ, Tasavvuf Terimleri Sözlüğü, (İstanbul: Kabalcı Yayıncılık, 2016), 153.

54 Kaya, Gönül Sultanları ve Hak Sohbetleri, 52.

55 Kaya, Gönül Sultanları ve Hak Sohbetleri, 341.

56 Kaya, Gönül Sultanları ve Hak Sohbetleri, 3419-351. 


\section{7. Hakîkat-ı Muhammediyye}

Hakîkat-ı Muhammediyye anlayışına göre Yüce Allah'ın zatı dışında hiçbir şey yokken Cenâb-ı Allah her şeyi bu hakikatten ve bu hakikat için yaratmıştır. ${ }^{57}$ Çelebi Süleyman Efendi de yaptığı yorumlarda bu inancı işlemiş ve savunmuştur. Ona göre Yüce Allah âlemleri yaratmadan önce Peygamber Efendimiz'i zât nûrundan yaratmış, kemâl ve cemâl sıfatlarına ayna kılmıştır. Kâinatın mayası $\mathrm{Hz}$. Peygamber'in (s.a.v.) rûhudur, bütün mevcûdatı onun nûrundan yaratmıştır. $\mathrm{Hz}$. Peygamberin nûrundan yaratılmasıyla insanoğlu esmâ-i hüsnânın sırrına mazhar olabilmiştir. ${ }^{58}$ Çelebi Süleyman Efendi'nin bu görüşleri sûfîlerin bu konudaki genel görüşleriyle uyum arz etmektedir. Nitekim Muhyiddîn İbn Arabî’ye (ö. 638/1240) göre de mahlûkat içerisinde alemin hülasâsı, insan-ı kâmil $\mathrm{Hz}$. Peygamber (s.a.v.)'dir. Diğer peygamberler ve kâmil insanlar insan-ו kâmil rütbesini vekaleten taşımaktadırlar. ${ }^{59}$

\section{8. Marifet Anlayışı}

Mutasavvıflar marifeti; Yüce Allah'ın zât, isim ve sıfatlarıyla tanınması şeklinde yorumlamaktadırlar. Marifet, ilimden çok iç tecrübeyle vasıtasız elde edilen bilgilerdir. Sâlik, nefsî arzularından uzaklaşıp arındığı ölçüde Cenâb-ı Hakk'a yaklaşır onun lütuflarına nail olur. ${ }^{60}$ Çelebi Süleyman Efendi de umum sufiler gibi marifetin Cenab-ı Hakk'ın veli kuluna bahşettiği vasıtasız Rabbânî keşif ve ilhamlar olduğunu söylemektedir. ${ }^{61}$ Yine Çelebi Süleyman Efendi, Hz. Peygamber (s.a.v.)'in sair insanlardan farklı olduğunu marifet derecelerinin zirvesinde olduğunu bildirir. "Yâ Rabbi seni layıkıyla bilemedik" hadisi şerifini şeyhinden nakille $\mathrm{Hz}$. Peygamber'in (s.a.v.) kabz halinde söylediğini ifade eder. Çünkü Yüce Allah tarafından $\mathrm{Hz}$. Peygambere bildirilmeyen bir şey yoktur. ${ }^{62}$

\section{9. İlhâm Anlayışı}

Tasavvufta Yüce Allah tarafından feyiz vasıtasıyla kalbe ilkâ edilen mana ve bilgilere ilhâm denilmiştir. ${ }^{63}$ Sûfîler, ilhamı dinde delil olarak görmüştür. Bu hususta bazı kelamcılar da onlara muvafakat etmiştir. ${ }^{64}$ Çelebi Süleyman Efendi şeyhinin kasidelerini yorumlarken ilhâm kelimesini “Yüce Allah'ın kalbe indirdiği

57 Muhyiddin İbnü'l-Arabî, Fütûhât-ı Mekkiyye, çev. Ekrem Demirli (istanbul: Litera Yayıncılık, 2007), 344-346; Süleyman Uludağ, Tasavvuf Terimleri Sözlüğü, 153; Kâşânî, Mu'cemu Istılahâti's-Sûfiyye, 82; Cürcânî, 80; Mu'cemu't-Ta'rîfât Rifat Okudan, "Hakîkat-i Muhammediyye Felsefî Temelleri ve Dînî Asıllarının Değerlendirilmesi", Süleyman Demirel Üniversitesi, Ilahiyat Fakültesi Dergisi, sayı: 2/11, (2003), 152.

58 Kaya, Gönül Sultanları ve Hak Sohbetleri, 3,5,197.

59 İbnü'l-Arabî, Fütûhât-ı Mekkiyye, 345; Refik el-Acem, Mevsuatu mustalahâti't-tasavvufi'l-islâmî, (Beyrut: Nâşirûn, 1999), 300-301; Mahmud Erol Klılıç, Şeyh-i Ekber, (İstanbul: Sufi Kitap, 2018), 74-75.

60 Süleyman Uludağ, Tasavvuf Terimleri Sözlüğü, 236; Dilaver Selvi,"Tasavvufta Marifetin Meyvesi Rahmet Ahlâkı ve Hizmet", Kafkas Üniversitesi Ilahiyat Fakültesi Dergisi 4 / Ek 1 (Aralık 2017), 87.

61 Kaya, Gönül Sultanları ve Hak Sohbetleri, 2.

62 Kaya, Gönül Sultanları ve Hak Sohbetleri, 197.

63 Ahmet Emin Seyhan, "Ebu'I-Hasan el-Harakânî’nin İlham Anlayışı", Usul İslam Araştırmaları 16 / 16 (Aralık 2011), Süleyman Uludağ, Tasavvuf Terimleri Sözlüğü,184; Selami Şimşek, Tasavvuf Edebiyatı Terimleri Sözlüğü, (Istanbul: Litera Yayıncılık, 2017), 175.

64 Seyhan, Ebu'l-Hasan el-Harakânînnin IIham Anlayışı, 85. 
bilgiler" şeklinde tarif etmektedir. ${ }^{65}$ Yine bağlı olduğu Nakşî-Halidî kolunun Pîrlerini ilhâma açık birer ârif-i billâh ve mürşid-i kâmiller olarak tavsif etmektedir. Yine tarîkat Pîrlerinden Şeyhi Meczûb Şeyh Muhammed Said Seyfeddîn'in açıklamalarının ilhâm-ı Rabbânî ile tasavvufta yeni bir manevî çı̆̆ır açtığını söylemektedir. ${ }^{66}$

\section{10. ìhlâs}

Tasavvufta ihlâs; kalbi bulandıran şüphelerden kurtulma, riyadan uzaklaşma, ameli Cenâb-ı Hakk'ın rızasını kazanmak için işleme şeklinde açıklanmıştır. ${ }^{67}$ Çelebi Süleyman Efendi ihlâsı; "muteber olan her şeyin kemali" şeklinde tarif eder. İhlâsın, ayeti kerime ve hadisi şeriflerin tevcihiyle ibadetlerin kabulünün esası olduğunu ifade eder. Çelebi Süleyman Efendi, kalpte siyah bir noktanın olduğunu ve Şeytanın kişiye buradan müdahale ederek ihlâstan uzaklaştırabildiğini söyler. ${ }^{68}$ Tasavvufun bu problemde devreye girdiğini, Yüce Allah'ın zikri ve kâmil mürşidin sohbetiyle bu siyah noktanın beyaz nûra dönüşebileceğini bildirir. İhlâsa erişebilmek için gayret gösterilmesi gerektiğini ifade edip bu hususta şu hadis-i şerifi nakleder: "Insanlar helâk oldu, ancak alimler müstesna. Alimler de helâk oldu ancak, ilmiyle amel edenler müstesna. illmiyle amel edenler de helâk oldu, ancak ihlâs sahibi olanlar müstesna. İhlâs sahibi olanlar da büyük bir tehlike içindedirler." ${ }^{\prime 69}$ Ona göre ihlasa erişmenin yolu ancak kendisi de ihlasa ermiş ve yetiştirmeye ehil mürşid-i kâmillerin sohbetleri ile mümkün olabilir. Hak yolunu gösteren kâmil şeyh, Allah'u Teâla'nın nûru ile kalbe teveccüh ettiğinde günahlarla simsiyah kesilmiş kalbi temizleyerek ilim, ihlâs ve ubudiyet şevki ile doldurur. Yine ona göre ihlâsa erişebilmenin bir başka yolu, Cenab-ı Hakk'ın nazar ettiği gönülde yer alabilmekten geçmektedir. ${ }^{70}$

\section{11. Aşk}

Çelebi Süleyman Kaya Efendi aşkı cemâl ve kemâl sıfatları gibi Yüce Allah'ın ezeli sıfatlarından görür. ${ }^{71}$ illahî aşka ulaşabilmenin yolunun ise kalplerin mâsivâdan temizlenmesiyle ${ }^{72}$ mümkün olabileceğini söyler. ${ }^{73}$ Aşkın kemale

65 Kaya, Gönül Sultanları ve Hak Sohbetleri, 323

66 Kaya, Gönül Sultanları ve Hak Sohbetleri, 51.

67 Yiğit, Yusuf en-Nebhânî ve Şiirindeki Tasavvufî Unsurlar, 102.

68 "Süveydâ-yı kalb denilen bu nokta kalbin ortasındabulunduğu farz edilir." Bkz. Şimşek, Tasavvuf Edebiyatı Terimleri Sözlüğü, 323.

69 İsmail b. Muhammed Aclûnî, Keşfu'l-Hafâ ve Muzîlü'l-illbâs amme'ş-tehera mine'l-Ehâdîsi alâ Elsineti'n-Nâs, thk. Ahmet Kalaş, (Beyrut: Müessesetü'r-Risâle, 1405/1985.), 2/312 (No. 2796).

70 Doğramacı, Kardeşim Süleyman Kaya'ya ithaf, 25.

71 Kaya, Gönül Sultanları ve Hak Sohbetleri, 5., Sûfîlerin ıstılahında aşk için şöyle denmiştir: "Aşk, ıstılâh-ı meşâyıhta Hakk'ın bir ismidir. Mâhiyeti medârik-i akl ve fehimden müteâlidir. Bkz. Selami Şimşek, Tasavvuf Edebiyatı Terimleri Sözlüğü, 43.

72 Çelebi Süleyman Efendi'ye göre bu temizlenme tek başına yapılan çabalarla olmaz. Ancak tarîkatta bir mürşidin kâmilin gözetiminde adabına uyarak yapılan seyr u sülûk neticesinde olabilir. Bu şekilde adabına riayet ederek alınan terbiye neticesinde ilahi aşk husule gelebilir. "Sâlik Allah-û Teâlâ'nın zikrini yapa yapa, Şeyh Hazretlerinin nûrlu kalbinde, o hatıraları, hayalleri götüre, götüre onun kalbinde işte o ilâhi duygu, evvelâ husûle gelir. O ilâhi duygu aşka döner." Bkz. ÇSK, "suleymankaya-kds.com".

73 Kaya, Gönül Sultanları ve Hak Sohbetleri, 4. 
ulaşabilmesi ve vuslatın vuku bulması için de mâşuktan başka hiçbir talebin olmaması gerektiğini vurgular. ${ }^{74}$

Çelebi Süleyman Kaya Efendi'ye göre hakikî aşka daha ulaşamamış olanlar tasavvur ve hayal ile kalbini temizleyip hakikate ulaşmaya çalışır. Bu konuda Mevlânâ Şeyh Ahmed el-Cezerî'den (v. 1050/1640) nakillerde de bulunûr. Mevlânâ el-Cezerî hakikî aşka ulaşmanın yolunun mecazî aşktan geçtiğini belirttiği beyitleri şu şekildedir: ${ }^{75}$

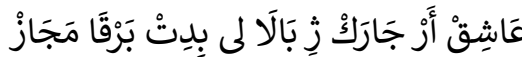

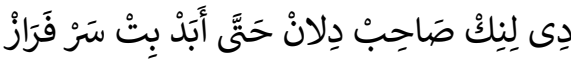

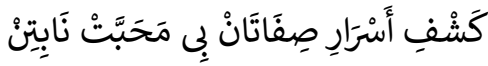

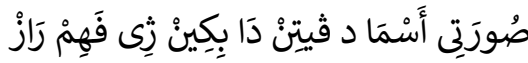

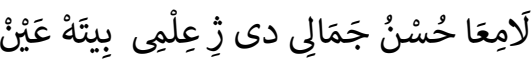

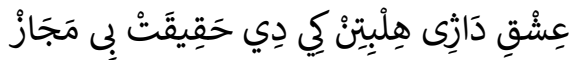

"Aşığa ulvi cihetten aşk-ı mecâzî şimşeği parıldarsa

Gönül ehlinin katında ebediyete kadar başı dik olur"

"Muhabbet olmadan sıfatların sırları anlaşılmaz

Anlayabilmemiz için esmanın sureti gereklidir"

“Hüsün ve cemal parıldadığında ilme'l-yakînden ayne'l-yakîne ulaşılır

Ta ki aşk ateşi alevlensin yoksa mecaz olmadan kim hakikate ulaşmıştı"

\section{Sonuç}

Tasavvufî düşüncesi çalışmamızın konusu olan Çelebi Süleyman Kaya Efendi, tasavvuf tarihinde merkezi bir konumda bulunan Cizre şehrinde doğmuştur. ilim tahsilindeki hocaları bilinmese de yaptığı tercümeler, açıklamalar ve sohbetlerden çok iyi bir dini eğitim aldığı açığa çıkmaktadır. Günün şartlarına göre iyi bir tahsil sayılan lise eğitimini de tamamlamıştır. Çok küçük yaşlarda Nakşî-Hâlidî tarîkatının meşhur şeyhlerinden Seyyid Muhammed Kadri Hazîn'e intisap etmiş bilahare ondan tasavvufî icâzet alarak halifeleri arasına girmiştir. Çelebi Süleyman Efendi hayatı boyunca azim ve gayretle Hak yolunu göstermeye çalışmış, dertlilerin imdadına koşmuş, insanların istikâmetten ayrılmamaları için çaba sarf etmiştir. Hedefi insan-ı kâmil yetiştirmek olan Çelebi Süleyman Efendi'nin gönüllere hitap eden sohbetini dinleyenler meclisini bir daha bırakamamış, hanesi kalbi kırıkların sığınağı olmuştur.

Tercüme, şerh ve sohbetlerinde düşüncesini beyan ederken atıfta bulunduğu ayetler, hadisler ve diğer kaynaklar muvacehesinde dini ilimlerdeki vukufiyeti hemen göze çarpmaktadır. Yaşamı boyunca İnsanların gönül dünyasına hitap etmeye çalışan Çelebi Süleyman Kaya Efendi'nin irşad ekseni sadece

74 Kaya, Gönül Sultanları ve Hak Sohbetleri, 339

75 Molla Ahmed ez-Zıvıngî, el-ikdu'l-Cevherî fî Şerh-i Dîvani'ş-Şeyhi'l-Cezerî, (Kamışlı: Matbaatu Rafideyn: 1958), 1/262-263. 
Müslümanlarla sınırlı kalmamış başka dine mensup insanları da kuşatmış ve birçok Hristiyan'ın İslamiyet'le müşerref olmasına vesile olmuştur. Onu tanıyanların ifadesine göre Çelebi Süleyman Efendi, Sünneti seniyyeyi kendisine rehber edinmiş ve şeriat-ı garrâyı tek geçerli ölçüt saymıştır. Hz. Peygamber'in güzel ahlâkını kendisine düstur ittihaz eden Çelebi Süleyman Efendi ince, kibar, zarif ve etkileyici kişiliğiyle Anadolu irfanının nûr kandillerinden birisi olmuştur. Zengin birikimiyle icra ettiği sohbetlerinde Kur'an ve Sünnete bağlılığı öncelemiş aynı zamanda kemâlât basamaklarını tırmanmak için bir mürşid-i kâmile bağlanmayı gerekli görmüştür. İnsanoğlunun en büyük imtihanı olan nefs-i emmâre ile yaptığı mücadelede ancak kâmil bir mürşidin gözetiminde başarılı olabileceği inancı sohbetlerinin temel konusu olmuştur.

\section{Kaynakça}

Aclûnî, İsmail b. Muhammed, Keşfu'l-Hafâ ve Muzîlü'l-ilbâs amme'ş-tehera mine'I-Ehâdîsi alâ Elsineti'n-Nâs. thk. Ahmet Kalaş. Beyrut: Müessesetü'r-Risâle. 1405/1985.

Attâr, Ferîdüddîn Tezkiretü'I-Evliyâ. çev. Süleyman Uludağ. 6. Basım. İstanbul: Semerkand Yayınları, 2018.

Cebecioğlu, Ethem. Tasavvuf Terimleri ve Deyimleri Sözlüğü. İstanbul: Ağaç Kitabevi Yayınları, 5. Basım, 2009.

Cürcanî, Ali b. Muhammed es-Seyyid eş-Şerif. Mu'cemu't-Tarîfât, thk. Muhammed Sıddîk el-Minşâvî. Kahire: Dâru'I-Fadîle. ts.

ÇP, Çankırı Postası. "Kürşad Erenbilge Mülakatı". Erişim 5 Ocak 2020. https://www.cankiripostasi.com/kursad-erenbilge-mulakti-1-makale,271.html

ÇSK, suleymankaya-kds.com. "Çelebi Süleyman Kaya (kds)". Erişim 10 Nisan 2020. https://www.suleymankaya-kds.com

Hücvirî, Ali b. Osman Cüllâbî. Keşfü'l-Mahcûb (Hakikat Bilgisi), çev. Süleyman Uludağ. 6. Basım. İstanbul: Dergâh Yayınları, 2018.

İbnü'I-Arabî, Muhyiddin. Fütûhât-ı Mekkiyye. çev. Ekrem Demirli. İstanbul: Litera Yayıncılık, 2007.

İmâm-ı Rabbânî, Ahmed Fârûkî Serhendî. Mektûbât-ı Rabbânî. çev. Abdülkadir Akçiçek. 2 Cilt. İstanbul: Çelik Yayınları, 2011.

Kâşânî, Abdurrezzak. Mu'cemu Istılahâti's-Sûfiyye. thk. Abdulâl Şâhin, Kahire: Dâru'lMenâr, 1992.

Kaya, Çelebi Süleyman. "1B", (1975), Erişim 2 Nisan 2020. https://www.suleymankaya-kds.com/sueleyman-kaya-celebi Kaya, Çelebi Süleyman. Gönül Sultanları ve Hak Sohbetleri. 3. Basım. Ankara: Kültür Ofset, 1996.

Kaya, Çelebi Süleyman. Sohbetler. haz. Sabiha Aşan. Ankara: y.y., ts.

Kelâbâzî, Ebubekir Muhammed. Doğuş Devrinde Tasavvuf (Ta'arruf). çev. Süleyman Uludağ. 6. Basım. İstanbul: Dergâh Yayınları, 2019.

Klııı̧, Mahmud Erol. Şeyh-i Ekber. 7. Basım. İstanbul: Sufi Kitap, 2018.

Kuşeyrî, İmam Abdülkerîm el-. er-Risâletü'I-Kuşeyriyye. thk. Ahmed Hâşim es-Sülemî. Beyrut: Dâru'I-Kutubü'l-IImiyye, 1434/2013.

Okudan, Rifat. "Hakîkat-i Muhammediyye Felsefî Temelleri ve Dînî Asıllarının Değerlendirilmesi". Süleyman Demirel Üniversitesi, ilahiyat Fakültesi Dergisi. 2/11, (2003), 139-164.

Öngören, Reşat. "Hatm-i Hâcegân". Türkiye Diyanet Vakfı İslâm Ansiklopedisi. 16/476-477. İstanbul: TDV Yayınları, 1997. 
Selvi, Dilaver. "Tasavvufta Marifetin Meyvesi Rahmet Ahlâkı ve Hizmet". Kafkas Üniversitesi Ilahiyat Fakültesi Dergisi 4 / Ek 1 (Aralık 2017): 85-155. https://doi.org/10.17050/kafkasilahiyat.372843

Şimşek, Selami. Tasavvuf Edebiyatı Terimleri Sözlüğü. İstanbul: Litera Yayıncılık, 2017.

Uludağ, Süleyman. Tasavvuf Terimleri Sözlüğü. 2. Basım. İstanbul: Kabalcı Yayıncılık., 2016.

Vâkıdî, Muhammed b. Ömer. Tarîh Futûhi'l-Cezîreti ve'l-Hâbûri ve Diyarbekr ve'l-Irak. thk. Abdülaziz Feyyad Harfûş. Şam: Dâru'l-Beşâir Li't-Tabâ'ati ve'n-Neşri ve't-Tevzi', $1417 / 1996$.

Yaşın, Abdullah. Bütün Yönleriyle Cizre. Basım Yeri Yok: Yücel Matbaacılık, 1983.

Yiğit, Mesut. Yusuf en-Nebhânî ve Şiirindeki Tasavvufí Unsurlar. Ankara: Fecr Yayınları, 2020.

Zıvıngî, Molla Ahmed. el-ikdu'I-Cevherî fî Şerh-i Dîvani'ş-Şeyhi'l-Cezerî. Kamışlı: Matbaatu Rafideyn: 1958. 